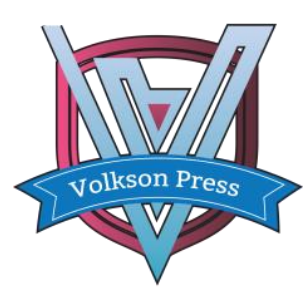

Contents List available at VOLKSON PRESS

Economics \& Management Innovations(EMI)

DOI : http://doi.org/10.26480/icemi.01.2017.151.153

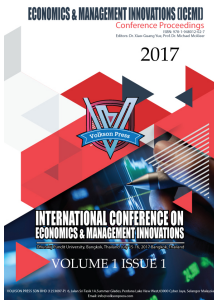

\title{
Executive power, Audit committee expertise and Internal control quality: An Empirical Analysis of China's A-share Markets
}

\author{
Ma Xiangyun*, Liu Shiping \\ Nanjing University of Science and Technology, Nanjing, PR China \\ *njnumxy@163.com \\ This is an open access article distributed under the Creative Commons Attribution License, which permits unrestricted use, distribution, and reproduction in any \\ medium, provided the original work is properly cited.
}

\section{ARTICLE DETAILS}

\section{Article History:}

Received 02 october 2017 Accepted 06 october 2017 Available online 11 october 2017

\section{Keywords:}

Audit committee expertise,

Internal control, Executive power,

Equity incentive..

\section{ABSTRACT}

The audit committee is responsible for improving the internal supervision, but executives may limit the audit committee effectiveness for self-interest. We choose all A shares in China during 2014-2016 as an example to research the effectiveness of audit committee expertise on internal control quality and whether the effectiveness will be weakened by the executive power. We found that (1) professional audit committee improves the company's internal control quality; (2) the executive power will weaken the audit committee effectiveness; (3) equity incentive will decrease the internal control quality and it may not mitigate the adverse effects of executive power on the audit committee effectiveness.

\section{Introduction}

The audit committee act as an independent third party in corporate governance, and is committed to improving the quality of financial reporting, monitoring the internal audit and designing the company's internal control system. Some research found the audit committee became more independent and professional after the introduction of SOX. However, recent studies take executive power into account and found that a dominating executive tends to undermine the audit committee effectiveness for his own interests (Wang Shouhai, 2012; Liu Yan, 2014). In view of this, we discuss whether the executive power have negative impact on the audit committee effectiveness. In addition, we study whether the company can take equity incentive measures to mitigate the manager's selfish motives, and then eliminate the negative impact. The research framework is shown below:

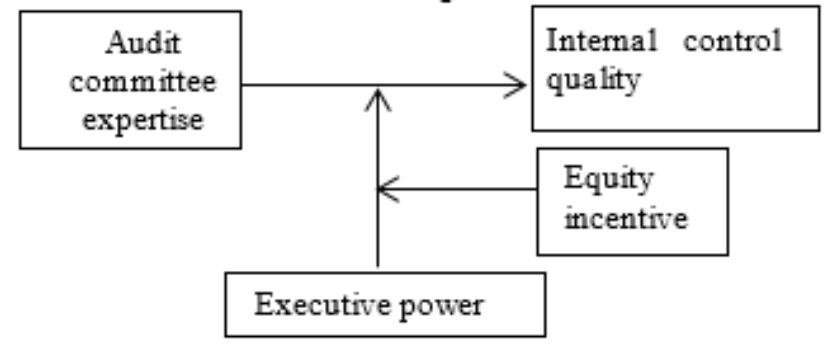

Fig. 1 Research framework

\section{Literature Review and Hypotheses Development}

\subsection{Audit Committee Expertise and Internal Control Quality}

The financial experts in audit committee help companies develop strategies. Specifically, the audit committee financial experts are better to understand the financial reporting and internal control, and thus can detect the major misstatement before the financial report disclosed (Sultana et al., 2015), as a result, it reduces the internal control problems (Hoitash et al., 2011). Dhaliwal (2010) believed financial experts in audit committee can improve financial report and internal control quality. Based on this, we propose the first hypothesis:
H1: The audit committee expertise is negatively associated with the internal control problems.

\subsection{Executive Power, Audit Committee Expertise and Internal} Control Quality

When the executives are powerful, they tend to provide the audit committee with low quality information, thus preventing the audit committee from exerting supervision function (Harris, et, al., 2008). The more powerful executives are more likely to have substantive control over the Audit Committee (Cohen, et, al., 2012). CEO power may result in an audit committee that appears effective in form but is not in substance. (Lisic, et, al., 2016). Thus, the effectiveness of the audit committee depends on the strength of executive power, and powerful executives will undermine the audit committee effectiveness (Guo Jun, Zhao Yue, 2015). Based on this, we propose the second hypothesis:

H2: The executive power undermines the role of the audit committee financial expertise in reducing internal control problems.

\subsection{Equity Incentives, Executive Power and Audit Committee Effectiveness}

If managers believe adverse internal control negatively affect the value of their equity holdings, equity incentives may urge them to strengthen internal controls (Steven, 2014). At this point, executives are motivated to assist the audit committee in exerting its functions. However, there are also some opposite argues claiming that managers can be protected from regulatory when their equity holdings reach a certain level. Based on this, we propose the third hypothesis:

H3: Equity incentive will mitigate the adverse impact of executive power on the audit committee effectiveness.

\section{Research Design}

\subsection{Sample Selection and Data Sources}

We choose all listed companies of A shares in China during 2014-2016 as an example, and excluded the following observations: (1) the financial industry companies; (2) the new listed companies; (3) the ST and PT companies; (4) the companies with missing information. Our final sample consists of 2335 firm-year observations. The financial data are all from 
CSMAR database.

\subsection{Definition of Research Variables}

Audit committee financial expertise (ACfin)

Audit committee financial expertise refers to the extent to which the audit committee have accounting or financial knowledge and practical experience. According to Liu Yan (2014), we take the proportion of financial expert members in the audit committee as a measure to the extent. The greater the indicator, the higher the audit committee financial expertise.

\section{Internal control deficiencies (ICD)}

We define the company whose internal control self-assessment report stating that it had internal control deficiencies, or whose auditor issued a non-standard internal control opinion as the company with internal control deficiencies, and ICD takes 1, otherwise 0 .

Executive power (Power)

\section{Table 3.1 Executive power measures}

\begin{tabular}{c|c|l}
\hline Dimensi-on & Indicator & Definition \\
\hline $\begin{array}{l}\text { Organiz-ational } \\
\text { power }\end{array}$ & Dual & $\begin{array}{l}\text { If CEO holds the position of } \\
\text { chairman, take 1, otherwise 0 }\end{array}$ \\
\cline { 2 - 3 } & Salary & $\begin{array}{l}\text { If the top three salary income } \\
\text { is greater than the industry } \\
\text { average, take 1, otherwise 0 }\end{array}$ \\
\hline \multirow{2}{*}{$\begin{array}{l}\text { Expert } \\
\text { power }\end{array}$} & Equity & $\begin{array}{l}\text { If executives hold shares in } \\
\text { the company, take 1, }\end{array}$ \\
\cline { 2 - 3 } & Top10 & $\begin{array}{l}\text { If the proportion of the top } \\
\text { ten shareholders is lower } \\
\text { than industry average, take 1, } \\
\text { otherwise 0 }\end{array}$ \\
\hline \multirow{2}{*}{$\begin{array}{l}\text { Owners- } \\
\text { hip power }\end{array}$} & Educa & $\begin{array}{l}\text { If CEO has a senior title, take } \\
\text { 1, otherwise 0 }\end{array}$ \\
\cline { 2 - 3 } & Title & $\begin{array}{l}\text { If CEO has a master's degree } \\
\text { or above, take 1, otherwise 0 }\end{array}$ \\
\hline \multirow{2}{*}{$\begin{array}{l}\text { Reputati- } \\
\text { on power }\end{array}$} & time & $\begin{array}{l}\text { If executives take part-time } \\
\text { jobs outside the company, } \\
\text { take 1, otherwise 0 }\end{array}$ \\
\cline { 2 - 3 } & Tenure & $\begin{array}{l}\text { If the CEO tenure is greater } \\
\text { than the industry average, } \\
\text { take 1, otherwise 0 }\end{array}$ \\
\hline
\end{tabular}

Equity incentives (EI)

We refer to Steven (2014) to choose executive equity returns sensitivity as equity incentive measure, that is the value of the changes of executive equity holdings when the stock price changes $1 \%$.

Control variables

The quality of internal control will be affected by other factors, so we refer to Lisic (2016) to select control variables. The variables and definitions are shown in table 3.2 .

Table 3.2 Definition of control variables

\begin{tabular}{c|l}
\hline & \multicolumn{1}{|c}{ Definition } \\
\hline Size & In(Total assets of the company) \\
\hline Age & $\begin{array}{l}\text { The years the company is listed on the } \\
\text { stock exchange }\end{array}$ \\
\hline Growth & Percentage of revenue growth \\
\hline Loss & $\begin{array}{l}\text { If net profit is negative, take 1, } \\
\text { otherwise } 0\end{array}$ \\
\hline ACsize & Number of audit committee members \\
\hline
\end{tabular}

\begin{tabular}{c|l}
\hline Big4 & $\begin{array}{l}\text { If the company was audited by the big } \\
\text { four accounting firm, take 1, otherwise 0 }\end{array}$ \\
\hline Audfee & $\ln$ (Audit fee) \\
\hline Year & $\begin{array}{l}\text { Sets two dummy } \\
\text { variables to }\end{array}$ \\
\hline Industry & $\begin{array}{l}\text { Set four dummy variables to represent } \\
\text { public utility, real estate, integrated, } \\
\text { industrial and commercial industries }\end{array}$ \\
\hline
\end{tabular}

\subsection{Design of Research Model}

To test H1, namely, the impact of auditor committee financial expertise on the quality of internal control, we design model (1):

$$
\begin{aligned}
\text { ICD }=\beta_{0}+\beta_{1} \text { ACfin } & +\beta_{2} \text { Size }+\beta_{3} \text { Age }+\beta_{4} \text { Growth }+\beta_{5} \text { Loss } \\
& +\beta_{6} \text { ACsize }+\beta_{7} \text { Big } 4+\beta_{8} \text { Audfee } \\
& +\varepsilon .
\end{aligned}
$$

To test $\mathrm{H} 2$, we add executive power variable, and the interaction between itself and audit committee financial expertise and then construct model (2):

$$
\begin{aligned}
\text { ICD }=\beta_{0}+\beta_{1} \text { ACfin } & +\beta_{2} \text { Power }+\beta_{3} \text { ACfin } \times \text { Power }+\beta_{4} \text { Size }+\beta_{5} \text { Age } \\
& +\beta_{6} \text { Growth }+\beta_{7} \text { Loss }+\beta_{8} \text { ACsize }+\beta_{9} \text { Big } 4 \\
& +\beta_{10} \text { Audfee }+\varepsilon .
\end{aligned}
$$

To test $\mathrm{H} 3$, we add equity incentives, executive power, audit committee financial expertise variables, and the interaction items between the two of them, and the three of them into model (1) and then construct model (3):

$$
\begin{aligned}
\text { ICD }=\beta_{0}+\beta_{1} \text { ACfin } & +\beta_{2} \text { Power }+\beta_{3} \text { ACfin } \times \text { Power }+\beta_{4} \text { EI } \\
& +\beta_{5} \text { ACfin } \times \text { EI }+\beta_{6} \text { Power } \times \text { EI } \\
& +\beta_{7} \text { ACfin } \times \text { Power } \times \text { EI }+\beta_{8} \text { Size }+\beta_{9} \text { Age } \\
& +\beta_{10} \text { Growth }+\beta_{11} \text { Loss }+\beta_{12} \text { ACsize }+\beta_{13} \text { Big } 4 \\
& +\beta_{14} \text { Audfee }+\varepsilon .(3)
\end{aligned}
$$

\section{Empirical Results}

\subsection{Descriptive Statistics}

Descriptive statistics of the major variables are shown in table 4.1. The mean of ICD is 0.49 , indicating that nearly half of the sample companies disclosed internal control problems in self-assessment reports or audit reports. The mean of ACfin is 0.182 , that is, $18.2 \%$ of the members in the audit committee are financial experts. The minimum of ACfin is 0 , indicating that there are still some audit committees having no financial experts.

Table 4.1 Descriptive statistics

\begin{tabular}{c|r|r|r|r}
\hline & \multicolumn{1}{|c|}{ Min } & \multicolumn{1}{c|}{ Max } & \multicolumn{1}{c|}{ Avg } & \multicolumn{1}{l}{ SD } \\
\hline ICD & 0.000 & 1.000 & 0.490 & 0.500 \\
\hline ACfin & 0.000 & 1.000 & 0.182 & 0.174 \\
\hline Power & -0.780 & 0.880 & 0.039 & 0.295 \\
\hline EI & 0.000 & 19.900 & 7.314 & 6.524 \\
\hline Size & 17.390 & 27.960 & 22.399 & 1.343 \\
\hline Age & 0.000 & 26.000 & 13.361 & 6.461 \\
\hline Growth & -1.670 & 1207.910 & 2.737 & 41.747 \\
\hline Loss & 0.000 & 1.000 & 0.102 & 0.303 \\
\hline ACsize & 0.000 & 13.000 & 3.586 & 1.380 \\
\hline Big4 & 0.000 & 1.000 & 0.050 & 0.218 \\
\hline $\mathrm{N}$ & 2335 & & & \\
\hline & & & &
\end{tabular}

\subsection{Regression Analysis}

We calculate the VIF values of all the variables in models before the regression and find that they are all less than 2 , indicating that there is no serious problem with multiple co linearity in the models. Table 4.2 presents the regression results.

Table 4.2 Regression results. 


\begin{tabular}{|c|c|c|c|}
\hline \multicolumn{4}{|c|}{ Dependent Variable: ICD } \\
\hline \multirow{2}{*}{ Independent Variables } & \multicolumn{3}{|c|}{$\begin{array}{c}\text { Coefficient Estimate } \\
\text { (t-statistic) }\end{array}$} \\
\hline & $(1)$ & (2) & (3) \\
\hline Intercept & $\begin{array}{c}1.803^{* * *} \\
(9.879)\end{array}$ & $\begin{array}{c}1.780^{* * *} \\
(9.700)\end{array}$ & $\begin{array}{l}1.77^{* * *} \\
(9.667)\end{array}$ \\
\hline ACfin & $\begin{array}{l}-1.879^{* * *} \\
(-41.203) \\
\end{array}$ & $\begin{array}{l}-1.859^{* * *} \\
(-40.604)\end{array}$ & $\begin{array}{l}-1.972^{* * *} \\
(-28.744) \\
\end{array}$ \\
\hline Power & & $\begin{array}{c}0.122^{* * *} \\
(3227)\end{array}$ & $\begin{array}{c}0.135^{* * *} \\
(2 \cap 41) \\
\end{array}$ \\
\hline ACfin*Power & & $\begin{array}{c}-0.579^{* * *} \\
(-3.814)\end{array}$ & $\begin{array}{c}-0.702^{* * *} \\
(-2.758)\end{array}$ \\
\hline EI & & & $\begin{array}{c}0.004^{* * *} \\
(2.191)\end{array}$ \\
\hline ACfin*EI & & & $\begin{array}{l}0.014^{* *} \\
(1.907)\end{array}$ \\
\hline Power*EI & & & $\begin{array}{c}-0.004 \\
(-0.705)\end{array}$ \\
\hline ACfin*Power*EI & & & $\begin{array}{c}0.006 \\
(0.264)\end{array}$ \\
\hline Size & $\begin{array}{c}-0.001 \\
(-0.134)\end{array}$ & $\begin{array}{c}0.001 \\
(0.019)\end{array}$ & $\begin{array}{c}-0.003 \\
(-0.365)\end{array}$ \\
\hline Age & $\begin{array}{c}0.005^{* * *} \\
(3.871)\end{array}$ & $\begin{array}{c}0.005^{* * *} \\
(3.8)\end{array}$ & $\begin{array}{c}0.007^{* * *} \\
(5.166)\end{array}$ \\
\hline Growth & $\begin{array}{c}0.018 \\
(1.179)\end{array}$ & $\begin{array}{c}0.016 \\
(1.167)\end{array}$ & $\begin{array}{c}0.111 \\
(1.265)\end{array}$ \\
\hline Loss & $\begin{array}{c}0.034 \\
(1.308)\end{array}$ & $\begin{array}{c}0.035 \\
(1.348)\end{array}$ & $\begin{array}{l}0.046^{* *} \\
(1.765)\end{array}$ \\
\hline ACsize & $\begin{array}{c}0.026^{* * *} \\
(4.479)\end{array}$ & $\begin{array}{c}0.027^{* * *} \\
(4.527)\end{array}$ & $\begin{array}{c}0.027^{* * *} \\
(4.587)\end{array}$ \\
\hline Big4 & $\begin{array}{c}-0.038 \\
(-0.947)\end{array}$ & $\begin{array}{c}-0.04 \\
(-1.015)\end{array}$ & $\begin{array}{c}-0.031 \\
(-0.794)\end{array}$ \\
\hline Audfee & $\begin{array}{c}-0.079^{* * *} \\
(-4.337)\end{array}$ & $\begin{array}{l}-0.08^{* * *} \\
(-4.418)\end{array}$ & $\begin{array}{c}-0.079^{* * *} \\
(-4.355)\end{array}$ \\
\hline Year & Yes & Yes & Yes \\
\hline Industry & Yes & Yes & Yes \\
\hline $\mathrm{N}$ & 2335 & 2335 & 2335 \\
\hline Adjusted $\mathrm{R}^{\wedge} 2$ & 0.437 & 0.440 & 0.456 \\
\hline
\end{tabular}

(4) deficiencies. However, the coefficient of ACfin*Power*EI is not significant, suggesting that the equity incentive measures cannot reduce or increase the effect of executive power on the audit committee. These findings do not accord with $\mathrm{H} 3$.

(5) As for the control variables: (a) The age is positively associated with ICD, suggesting that as the companies gradually entered the recession stage, it leads to the failure of internal control. (b) The size of the audit committee is positively related to the ICD, showing that increasing the number of members without financial experts may lead to redundancy and decrease internal control quality. (c) Audit fees are negatively related to ICD, indicating that external auditors have made additional efforts to ICD remediation, thereby increasing the audit fees.

\section{Robustness Test}

In order to ensure the robustness of the results, we have done the following additional tests: (1) We choose ICD remediation and the financial restatements as dependent variables to replace ICD, and it further verify the H1. (2) We add the value of eight variables measuring executive power to replace the comprehensive index, and its range is from 0 to 8 . The greater the value, the greater the executive power. The results are still consistent with the original empirical results.

\section{Conclusion}

The research shows that: (1) The higher the proportion of financial experts in audit committee, the less the possibility of internal control deficiencies. (2) Too strong executive power will undermine the audit committee effectiveness. (3) Equity incentive measures increase the internal control deficiencies. However, equity incentive measures cannot aggravate or mitigate the adverse impact of executive power on the audit committee effectiveness.

The contributions of this paper are as follows: (1) In order to improve the Internal control quality, the company should pay attention to select or train more financial experts for audit committee. (2) The shareholders should allocate the power reasonably and improve corporate governance. (3) Equity incentive is widely believed as the coordination measures between shareholders and managers, but the company cannot simply apply the measure to improve the internal control quality.

\section{Acknowledgements}

This paper has greatly benefited from comments from Wang Congcong, Yao Jing, Professor Han Xiaomei and anonymous reviewers.

\section{References}

[1] Wang Shouhai, Li Yun. Management intervention, audit committee independence and earnings management [J]. Auditing research, 2012 (4): 68-75.

[2] Liu Yan, Yao Haixin. Executive power. Defects in the professional and internal control of the audit committee [J]. Nankai management review, 2014 (2): 4-12.

[3] Faleye O, Hoitash R, Hoitash U. The costs of intense board monitoring[J] Journal of Financial Economics, 2011, 101(1): 160-181.

[4] Lisic L L, Neal T L, Zhang I X, et al. CEO Power, Internal Control Quality, and Audit Committee Effectiveness in Substance Versus in Form[J]. Contemporary Accounting Research, 2015.

[5] Yu Haizong, Wu Yanling. The effectiveness of equity incentive and internal control quality [J]. Audit research, 2015 (5): 57-67

[6] Guo J, Huang P, Zhang Y, et al. The effect of employee treatment policies on internal control weaknesses and financial restatements[J]. The Accounting Review, 2015, 91(4): 1167-1194.

[7] Bi Xiaofang, Han Chuanmo. Study on the relationship between equity incentive contract and earnings quality [J]. Auditing and Economic Research, 2012 (2012, 06): 75-82.

[8] Sultana N, Mitchell Van der Zahn J L W. Earnings conservatism and audit committee financial expertise[J]. Accounting \& Finance, 2015, 55(1): 279-310.

(3) Model (3) shows a significantly positive coefficient on EI, suggesting that the equity incentive is positively associated with internal control 